\author{
PAPP, SÁNDOR
}

papp.sandor.geo@gmail.com

PhD student (Department of Economic and Social Geography, University of Szeged)

\title{
Community resilience in post-socialist rural areas
}

\section{The case of grape- and wine-producing communities in the Soltvadkert and Minis-Maderat areas}

\begin{abstract}
Resilience thinking has become an increasingly popular topic in both academic and policy-making circles due to its normative interpretation, which assumes that resilience is the opposite of vulnerability. Vulnerable groups, communities, settlements, regions and nations have a greater likelihood of facing more serious consequences in the event of unpredictable, negative shocks. Based on this view, in general, rural communities and regions can be considered more vulnerable and hence less resilient to unknown, negative events, as the subsistence of these communities is more closely linked to their environments rather than to people living in urban areas. This is further exacerbated by the path dependence of having a post-socialist past: the 'legacy' of socialism that, in many cases, includes a relatively disadvantageous position, backwardness and intensification of peripheralisation processes. While there is no consensus on the concept of resilience itself, there are several approaches and perspectives related to possibly detecting signs of its existence in rural communities. Our aim to present how the notion of resilience can be operationalised at the farm level in post-socialist contexts based on three different perspectives in order to contribute resilience thinking related to post-socialist discourses. We illustrate how rural community resilience may be conceptualised based on the example of the grape- and wine-producing communities of Soltvadkert, Hungary and the Minis-Maderat wine region, Romania. Based on our qualitative methodological results, it can be stated that the resilience of a community or group, its properties reflecting resilience can be interpreted in several ways, which is partly location-dependent, partly path-dependent, however, it is highly dependent not
\end{abstract}


only on embedded structures but also on activities that are constantly reproduced by community members.

\section{KEYWORDS}

resilience, farming, wine makers, wine region, Central-Eastern-Europe, ANT

DOI 10.14232/belv.2020.3.5

https://doi.org/10.14232/belv.2020.3.5

Cikkre való hivatkozás / How to cite this article:

Papp Sándor (2020): Community resilience in post-socialist rural areas. Belvedere Meridionale vol. 32. no. 3. 59-75. pp

ISSN 1419-0222 (print)

ISSN 2064-5929 (online, pdf)

(Creative Commons) Nevezd meg! - Így add tovább! 4.0 (CC BY-SA 4.0)

(Creative Commons) Attribution-ShareAlike 4.0 International (CC BY-SA 4.0)

www.belvedere-meridionale.hu

\section{INTRODUCTION}

The notion of resilience has gained large momentum in the multidisciplinary field of research and in policy-making circles in the past 20 years (DARNHOFER et al. 2016, WILSON 2017). Due to its popularity and wide application, several authors claim that it is a fuzzy meaning catchword (SzÉKELY 2015), while others argue that many research under-theorized, simplified or misused (WILSON 2017, LENDVAY 2016). Based on the fruitful debate, which can be observed in the field, related to its views, approaches, types or definitions it is crucial to clear the answers for two fundamental questions when we analyze it - resilience to what, and resilience for whom - which are ultimately depend on disciplinary background, perspective and problem focus (CUTTER 2016).

Beyond that, it is also important to mention that there are basically two approaches which distinguish between normative and neutral interpretations of resilience. The normative approach is based on the assumption that resilience-vulnerability are seen as oppositional terms and where resilience is a desirable outcome mostly from human action (ADGER 2000). That is the reason why it is so popular in policymaking, because its application provides clear guidelines for decision-makers to find solutions to improve their environment, or its structures. An opposing view is that resilience is a neutral concept that can be either "good" or "bad". Usually this is illustrated by situations that seem "resilient" but could be perceive as negative for the long-term adaptive 
capacity of a "system" or even a community, such as "resilient" lock-in processes associated with extreme income disparities, unequal power and governance structures (WILSON 2017).

As the Common Agricultural Policy (CAP) makes almost 40 percent of the European Union (EU) budget (EUROPARL.EUROPA.EU 2020), and because family farms account for more than $90 \%$ of agricultural holdings (EC.EUROPA.EU 2020), these businesses are of great importance not only from an economic, but also from a food safety point of view. Although individual and/or family farms in the Member States are eligible for relatively significant support, they cannot be treated in the same way, either in terms of the amount or form of support, as they face different challenges in terms of their geographical environment, economic, social and cultural environment and sector (BEKE 2011). In most cases, bottom-up intervention can only take place in a limited way, however, top-down intervention is not necessarily possible, so it is essential to get to know and present place-specific case-studies as widely as possible in order to be able to plan and consciously respond to foreseeable and unforeseen threats (MARTIN - SUNLEY 2015).

At the same time, many authors draw attention to the unique semi-peripherical situation, political, economic, and cultural environment which can be observed in Central and Eastern Europe (CEE) within which, resilience interpretation may be different from other parts of the world (NAGY - Timár 2017, Neugebauer - Kovács 2015). According to Lendvay (2016) the post-socialist transition, a process which has been lasting for 30 years includes many specific characteristics which contribute to the environment which, inter alia, justifies a reinterpretation of the application in the local context. These are the mixture of the images of the pre-socialist era, the legacies and memories of socialist past, the images that were created after the regime shift and during the accession to the EU with its accompanying processes, and the personal stories of the community members that determine how they relate to these (LENDVAY 2016). This is one of the main reasons why resilience of the studied group, community, area, region cannot be analyzed without an interpretation of its historical past and wider geographical environment (BROWN - KulIG 1996).

The literature on resilience has grown exponentially over the past 10 years, resulting not only in a number of theoretical innovations but also in a significant amount of practical application with a wide variety of sample areas and case studies (Tóтн 2015, AshKENAZY et al. 2018). Due to the vast amount of literature, the present work does not aim to fully collect and summarize its results to date. Many authors have already tried to do this before us (MARTIN - SUNLEY 2015, WILSON 2017). Nor is it intended to call into question the usability of results that can be linked to theoretical discourses or different perspectives. The aim of our study is to show how the idea of resilience affecting rural communities can be interpreted mainly in the two selected rural sample areas and communities, within the post-socialist framework, thus contributing to the expansion of the literature on resilience and the number of available case studies.

\section{Methodology}

This study based on non-representational methods (VANNINI 2015) believing that aspects of resilience may not be directly observable and measurable (DARNHOFER et al. 2016). At the same time, we argue that a complex and multi-faceted concept like (community) resilience hard to be measured with aggregate quantitative analysis due to lack of systematically collected and 
available data. Furthermore, a qualitative case study method could provide the opportunity for nuanced assessment of a locally-specific interpretation of resilience which can be used as a practice to other groups, stakeholders and decision-makers (FOSTER 2006).

Between December 2019 and April 2020, 20 semi-structured in-depth interviews were conducted in the study areas with farmers, winemakers, traders, decision-makers, and other experts. Most of the interviews were conducted before the COVID-19 pandemic, therefore, we did not aim to investigate its effects. The reason for choosing these areas is that both situated in a "predominantly rural region" in 2011 (EC.EUROPA.EU 2011), while based on the reformed typology of 2018 they became "intermediate regions" (EC.EUROPA.EU 2018) which, in addition to the changing typology, partly reflects local urbanization processes and the relative decline in the economic weight of agriculture. Furthermore, both areas are strongly connected to grape and wine producing which can be traced back to a relatively long history and also it is still a dominant economic activity in the region (Figure 1).

However, many authors argue that when examining resilience, special emphasis should be placed on the analysis of various local and higher-level development documents, which indirectly or even directly, top-down affect the resilience of a community or region (AsHKENAZY et al. 2018), which is not covered in our present work. This will be the subject of an other work, with the main emphasis on business and tourism development plans and concepts affecting the two regions and its grape- and wine makers, which provide the vision and potential envisaged by local decision-makers.

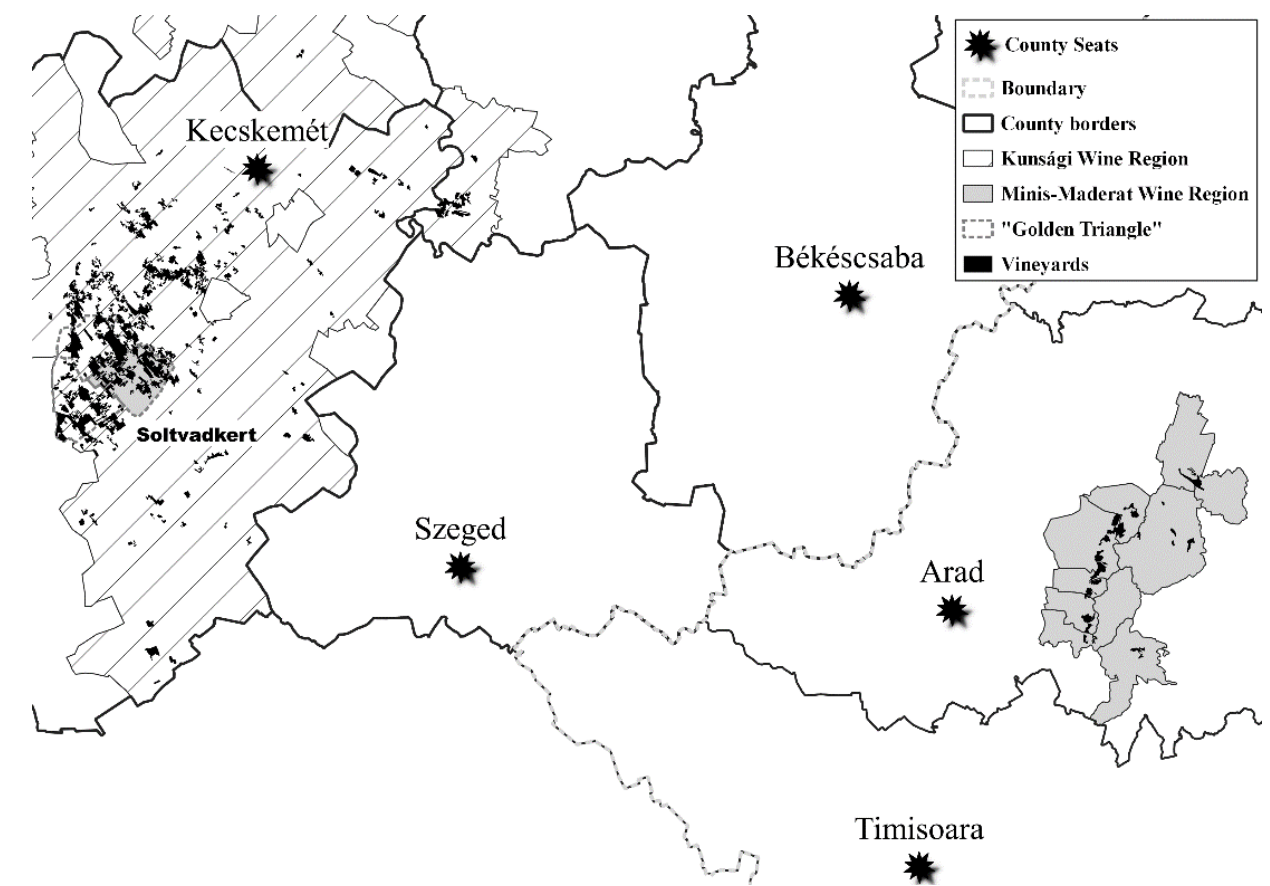

FIGURE 1. Study area (Source: Corine Land Cover 2018 data, edited by the author) 


\section{THEORETICAL BACKGROUND}

In recent years, the term resilience has become important not only in the field of ecology or psychology, but in human geography, agriculture and rural development as well (see for example (Lin 2011, Herman 2015, AshKenazy et al. 2018). Basically, most of the works connected to rural community resilience apply two different approaches, which are the social-ecological-systems (SES) and the community psychology (LENDVAY 2016). Many authors argue that, however, actor-network-theory (ANT) offers allows for a more complex and comprehensive analysis related to resilience (DARNHOFER et al. 2016, DWIARTAMA - ROSIN 2014).

In the literature, resilience is often linked to the name of HolLING (1973) in ecological science, who originally understood as an ability of a system to manage or cope with change. Based on his main idea and approach of SES WALKER ET AL. (2004, p. 2) defined resilience as "the capacity of a system to absorb disturbance and reorganize while undergoing change so as to still retain essentially the same function, structure, identity and feedbacks". SES approach is based on the idea that human beings live in a complex, integrated, multilevel and multiscale interconnected system in which they should be considered as a part of nature (BERKES-FoLKE 1998).

On the other hand, there is an other approach, which derived from community psychology (GARMEZY 1973, LENDVAY 2016) focusing on the adaptive capacities of individuals and groups, and their ability to recover after a disaster or to follow a single development pathway (SCOTT 2013). Based on its main point of view and research focus (partly due to criticism of the unsatisfactory social theoretical system of SES), a community psychological stream examining different social groups, which can be found in the literature as community resilience or social resilience (BROWN 2014, KECK-SAKDAPOLRAK 2013). It examines a group of individuals, whose social structure, relationships, and internal dynamics determine how to act in a way that is built from a physical or social event that they perceive as negative. Brown-Kulig (1996, p. 1) defined resilience as "a fundamental human potential which is both enabled and constrained by the social contexts people construct and within which they carry out their daily lives". Furthermore, it adds a crucial dimension to the analyses as it "emphasizes identifying and developing community strengths, and building resilience through agency and self-organization, with attention to people-place connections, values and beliefs, knowledge and learning, social networks, collaborative governance, economic diversification, infrastructure, leadership, and outlook" (BERKES-Ross 2013, p. 5).

As there is a perceptible gap between the two approaches, which resulting different kinds of shortcomings through multidisciplinary research, several authors have tried to apply a new "relational" approach to examine and understand rural resilience and its "components", which focusing on interactions rather than entities (DWIARTAMA - ROSIN 2014, DARNHOFER et al. 2016, LENDVAY 2016). We agree with LENDVAY (2016, p. 258) about that "human geography should dissolve the theoretical dichotomy and treat both large scale structures and agency of individuals on the common ontological framework". ANT developed by LATOUR (2005) put emphasis on relationships in which "agents" participate, who are understood as inseparable from the spatial and temporal contexts within which they are embedded. Taking this perspective, we can see "farming" instead of farm and/or farmer, and "becoming" instead of "being" (see DeLEUZE - PARNET 1996), which refers to an on-going transformability of relationships between agents 
and/or non-human actants (CHIA 1999). This leads to that "resilience is not a 'thing'that can be seized, held or measured, it is not an attribute or property of a farm or a farmer. Rather, resilience is the emergent result of ever-changing patterns of relations, relations that are material, social, cultural" (DARNHOFER et al. 2016. 118).

\section{Aspects of Community Resilience}

\section{Grape- and wine production in Soltvadkert}

Soltvadkert town has the largest vineyard area ( $\sim 3000$ hectares) within Hungary's largest wine region, the Kunsági Wine Region ( $\sim 21000$ hectares). Viticulture and wine production are based on old traditions in the area. Vines were planted in the region, mainly to bind quicksand, which dates to the 19th century. The devastating large phylloxera epidemic around the middle of the 19 th century was avoided due to its high quartz content, sandy topsoil. In addition to the binding of quicksand, the livelihood was mostly forced to establish vineyards and orchards on gentler sand dunes, as their roots were able to penetrate deeper into the groundwater even where field cultivation and its success were uncertain (MOLNÁR 2003). In the socialist period, unlike in a significant part of Hungary, mainly due to the average gold crown value of the lands, trade unions have been set up instead of producer cooperatives, which do not obliged participants to participate in joint work. The members were able to carry out individual farming for a certain fee. These trade unions participated in the domestic and export sales of the wines, integrating the producers, which meant mainly the production of large quantities of uniformly non-outstanding quality for the eastern market and which provided a substantially risk-free source of income. For this reason, it is perhaps no exaggeration to say that a significant number, if not all, of the families living here owned more or less vineyards, thanks to which they could gain economic benefits in one way or another. Initially, the area was called the "Golden Triangle" (GT) because it was this area where was best to make a living from agriculture (INDEX 2019).

After the regime shift, from the early 1990s, circumstances changed significantly. The centralized state farms went bankrupt, a significant part of the trade unions disintegrated, the compensation process started and the majority of farmers, focusing on individual farming as far as possible. In a sense, many farmers benefited from the period of reparation, as they, thanks to the tacit knowledge (and not incidentally capital) accumulated from the greater "backyarding" during socialism, adapted more easily to the possibilities of a capitalist market economy. The problem stemmed from the accumulation of unsold inventories and the disintegration of previous markets. Thanks to the previous quantitative approach, there was a large amount of wine in the cellars, which, even if there was a demand, had to be delivered to the consumer. However, from the second half of the ' $90 \mathrm{~s}$, the area became famous for something else and the title GT was given a different interpretation. Due to the geographical features of the area and the ingenuity rooted in the past, the activity of counterfeiting oil began to develop and flourish, which often proved to be a motive for acts of violence. As this period subsided, a wave of "wine splashing" further strengthened the reputation of the GT, based mainly on the re-use of capital and technological conditions (barrels, tanks) accumulated from oil 
bleaching. According to several interviewees, the perception and presentation of Great Plain wines in a negative light began to change, especially from that time, which is partly due to the great popularity and collective stigmatization in the national media. Although producers who previously carried out counterfeiting in large volumes have ceased to do so, thanks in part to official tightening, honest winemakers are still forced to suffer the disadvantages of this legacy (ScHWARCZ 2003).

An important milestone in the agriculture of the CEE countries is the accession to the EU, on which there are also divisive opinions among winegrowers and winemakers. Although, overall, the CAP has fundamentally brought predictability, transparency and many new opportunities for countries' agriculture, there have also been a number of difficulties with accession. It resulted in varying degrees of success among the countries that joined after 2004, but also within agricultural sectors, as, for example, in new markets, with more competitive Western competitors, domestic farmers had only limited ability to cope. Similarly, the mass emergence of multinational food processing and trading companies has led to new conditions, an increase in the proportion of products from abroad, and the introduction and adherence to often stricter EU standards has not necessarily benefited domestic producers. Of these, the situation of small farms with less financial resources and less international market relations, has become more difficult (CsÁKI JÁMBOR 2012).

First, the changed market conditions and regulations associated with the regime shift, and later with the accession to the EU, require the change of the strategies of wine growers and the adaptation to them. However, not all farmers are able to adapt to this, and many, especially elderly winegrowers, have chosen to close, sell / lease their land, or cease their individual wine production. According to an interviewee, only in Soltvadkert, out of nearly 600 farmers who filtered their wine 30 years ago, a tenth of it continues this activity today. At the same time, the concentration of land and the transformation of the fragmented estate structure can be observed, as fewer and fewer people are dealing with this, but in larger and larger areas in order to be profitable. Most farmers who choose this path have abandoned the "fuss" of winemaking, preferring to remain "comfortable" in the cultivation of high-yielding varieties such as Bianca and, after harvest, sell their produce to larger wineries, which are mostly (not exclusively) sell in PET bottles as low quality table wine. For the most part, these 4-5 "multi-wineries" in the area set the maximum price per kilogram they are willing to pay for grapes produced by farmers, which creates a large-scale, relatively one-sided dependency. An excellent example of this was the 2019 grape price situation, which was criticized by several interviewees. Compared to the average prices of the last 7 years and measured in the interests of profitable operation, the farmers were able to sell their crops much lower, which on average accounted for half of their income. Events like these threaten smaller producers year after year, who are largely engaged in monoculture production and are vulnerable to buyers.

However, some farmers have chosen a different path, in whole or in part, and have moved towards quality wine production. They try to establish their market presence and strengthen their position by replacing outdated technologies, selecting special varieties, selling them in bottles and participating in domestic and international wine competitions. Within this, we can separate a layer that, in addition to its production activities, partly promoting it, based on the strategies observed in the better-known foreign and domestic wine regions, tries to open up 
to wine tourism. Various hospitality-related off-farm services (wine tasting, accommodation, meals, other events) are offered to interested tourists, with more or less success in order to being less vulnerable. By expanding their economic activity, they can earn a safer income, which, however, does not happen overnight (ASHKENAZY ET AL. 2018). The majority of these grape and wine growers are farmers, who usually have neither hospitality nor particularly specific management knowledge, which greatly slows down the process.

In addition to economic challenges, as is generally the case in agriculture, a number of natural environmental challenges and 'non-human actors' also jeopardize farmers' activities and affect their success. The climate of the area is being examined by a number of studies which call attention to its high vulnerability to climate change, drought and desertification, which may have a strong impact on agricultural production in the area, including economy and society, in the future (BAJMócy et al. 2005). In addition, extreme weather events, lightning floods, hailstorms and various unprecedented or cyclical pests, which are becoming more frequent as a result of global climate change, are all constantly challenging and forcing farmers to adapt. Related to this it can be mentioned the efforts of some farmers to envisage their economic activity by abandoning viticulture and afforestation of land, which could pose new environmental and economic challenges to the community (TöLGYESI et al. 2020).

\section{Grape- and wine production in Minis-Maderat Wine Region}

Minis-Maderat Wine Region located in the South-Western part of Romania, 40 kilometers from the Romanian-Hungarian boundary, in Arad county. Of the 37 wine regions in the country, this is considered to be one of the oldest wine regions in the Carpathian Basin (CsÁvossy 2016). It forms an approximately $50 \mathrm{~km}$ long N-S strip between the Fehér-Körös and Maros rivers, on the western side of the Zarand Mountains. Its area approximately 3000 hectares, on which is dominated by red wines, of which Cabernet Sauvignon, Pinot Noir, Cadarca, Merlot and Burgund are the most popular, but it can find also Riesling Italian, Fetească regală and Muscat Ottonel (MăLĂESCU et al. 2014). Written memoirs from the 11th century mention vineyards in the landscape, which have undergone several ordeals over the centuries. As a result of the stormy times of the 17th century, they suffered enormous damage and were one of the wine regions almost completely destroyed by the great phylloxera disaster. He lived his heyday around the end of the 19th century and the beginning of the 20th century (MóD - SimON 2008). In the period following the events of 1947 , the proportion of economic sectors to be nationalized in the country was constantly expanding, which resulted in the socialist-type transformation of agriculture and the radical transformation of rural land ownership. The established producer cooperatives and collective farms grew grapes within the framework of planned management, which were processed by the state cellar farms and sold mainly to the eastern markets (LÁszLó 2013).

With the regime shift, the previously nationalized land was reprivatized, which, contrary to the Hungarian practice, was not solved with compensation certificates, but was returned to the previous owners by application. In practice, however, this has resulted in a fragmented estate structure and inefficient management. Based on the principle of economies of scale and taking 
into account the previous quantitative point of view by the farmers, the aging social structure and the lack of knowledge of new market mechanisms, individual farming has become quite difficult. The three large local state-owned companies (VINALCOOL, VINEXPORT, Baracka Viticulture and Enology State Farm) have also been privatized, but less successfully than in other parts of the country, the equipment has been sold or simply lost track and a significant part of the land has fallen into foreign hands, or lying fallow.

Accession to the EU has also brought huge opportunities to this region. Various land-based and restructuring subsidies have improved the opportunities for many landowners. Ownership conditions also changed after accession, as previously the purchase of land ownership by foreign nationals was not allowed, thus generating even more foreign investors. The settlements were able to implement a number of infrastructural investments, with which they improved their accessibility and the living conditions of the inhabitants. Also, as the economic crisis of 20082009 coincided more or less with the period of EU accession, farmers were less affected. The Podgoria Minis-Maderat Local Action Group has been set up to try to coordinate the work of local actors and to assist in the mobilization and use of European Union funds.

However, in addition to the opportunities, it also brought some difficulties, which are related to the CAP, the forms of support and their use. EU regulations restrict the establishment of new vineyards and the renewal of old ones in all countries, especially in order to avoid overproduction. Romania does not differ from this either, as the extent to which the country's wine-growing area can be expanded or replanted is also regulated here. In the 2007-2013 programming period, Romania was able to draw on almost $€ 290$ million for viticulture and oenology, more than $90 \%$ of which was used for vineyard reconstruction and conversion (ANTOCE - CALUGARU 2017). This is particularly positive in that the old plantations, which are less suitable for market conditions, have been renewed and a more diverse variety portfolio has been developed, both nationally and often locally. However, there is also some criticism in this regard, as the vast majority of grants were available for this purpose, not for technological innovation or, for example, for expansion with various off-farm activities. Thus, a person who had a vineyard or land, applied for support without a longer-term purpose, which he used only partially for that purpose and, in a good case, left it fallow while waiting for the end of the maintenance period. In addition, a number of other, partly gray, speculative activities related to EU support for vineyards have been mentioned, which also hamper the efficient use and utilization of resources on the one hand and vineyards on the other.

The large influx of foreign direct investment observed after the regime shift into the western counties of the country, most notably the counties of Timisoara and Arad, resulted in a largescale development, which did not leave the agricultural sector untouched either (CRETAN et al. 2005). This trend has not diminished in the years of accession to the European Union (CEICDATA 2020). Although a foreign citizen could not have exclusive land ownership until 2014, according to a 2015 report, nearly 40 percent of the country's agricultural land owned by foreign investors (RomAniA-INSIDER 2017). This is due, among other things, to the land policy that is relatively liberal in Europe, the low land prices, as well as the opportunities or lack of opportunities for domestic farmers. The presence of foreign investors and/or owners in agriculture, viticulture and wine production can also be observed in the region. Many of the cellar owners are not local or Romanian native speakers, but are indirectly connected to the area, have started a business 
here, or form an ownership share only as an investment.

Typically, operating companies with foreign interests are not satisfied only with viticulture, but also with their own quality winemaking, which is usually carried out in a smaller area, seeking to use modern technology. In terms of proportions, there are not many wineries, roughly 10-15, among whom 2-3 dominant players have more than 80 hectares of land. Other smaller wineries farm on an average of 15-40 hectares, as wineries usually make their wines partly from their own crops and partly from grapes bought from other winegrowing farmers. The set, which accounts for nearly 80 percent of producers, is made up entirely of winegrowing farmers, who are usually locally affiliated and sell their products to other local or non-local wineries. Based on the interviews, it can be said that the majority of producers consist of older farmers, accustomed to socialist conditions, less willing to innovate, with limited opportunities, who tend to take a quantitative rather than qualitative approach and who consider their own independence to be paramount. Perhaps they are the most vulnerable players here too, as their revenues depend on grape prices and some sell locally produced grapes, others sell in bulk their lower quality, lower value-added wines. In the neutral meaning of the term, it can be claimed that these growers are the most resilient players, but unfortunately on the bad way, as they locked-in the socialist circumstances with less adaptability and high level of rigidity.

In addition to economic and social factors, natural ones also play an important role in this area. Global climate change does not affect few places on Earth and its signs have already been seen in the study area. The wine region has an advantageous position in terms of grapes and wine production due to its topography and climatic conditions. Rising temperatures and falling rainfall due to climate change, extreme weather events, but also the emergence of various pests associated with them all put vines, and thus farmers' living conditions at risk (SIMA et al. 2015).

\section{DISCUSSION}

Resilience can be examined in a number of ways in the case of the two groups, which can be linked to agricultural activity. Considering the historical and current circumstances, as well as examining the geographical and structural environment within the groups and their wider context, the literature tries to interpret the concept of resilience based on two common perspectives. To bridge the differences between the structural and agency approaches, the ANT approach is being used in more and more work, which may provide a solution to the tensions arising from the dichotomy of the two approaches (LENDVAY 2016).

We can examine the individual farms, lands, plantations that convey resilience in a given area. This is mainly due to their biophysical appearance, which depends on the size of the land, the relief conditions, or even the climate. It can also mean the agro-ecosystem of a plantation, which depends on soil quality, nutrient supply, the type of grapes produced, the type of cultivation, biodiversity, etc. Furthermore, different social structures (markets, different regulations) that determine the production on the land may play a role in this. If we look at it from this point of view, the focus should mostly be on the properties of the land, which can be influenced to some extent but cannot be changed. This is usually limited to the change between the quantity / quality of the crop and the cultivator of the land, its activity, which 
presupposes atomized decision-making processes, often without the need for a broader social medium (DARNHOFER et al. 2016). This can be examined in terms of the geographical and geological conditions of the two areas, which affect the possibilities, limitations and justifications for growing certain grape varieties, as well as the quantity and quality of the wines made from them. The studies related to that view also include what tenure conditions can be observed in the area, which ones can sustain themselves economically, safely and flexibly; the degree of diversity of each farm, the number of varieties of grapes grown and, in a broader sense, the type of cultivation.

Resilience manifests itself as a kind of flexible and prepared production and management activity that takes advantage of the given area (and structures) which tries to resist or adapt to as many types and degrees of negative disruption as possible (drought, ice damage, pests, changes in demand). As a concrete example, the Hungarian sample area was placed by winegrowers who abandoned their production activities in several waves, when with the change of market conditions it was no longer worthwhile to farm in a smaller area, which seems to have continued ever since. In contrast, however, a circle has emerged or is emerging that, although not with uniform strategies and goals, produces on a larger area of land. A similar process can be observed in the Romanian sample area. In both areas, there is also a search for a balance between typically local and more popular world varieties and the production of more laborious, more delicate and less demanding, more resistant grape varieties as a result of efforts to find safer sources of income.

From natural and/or "non-living" actants, we can shift the focus to social actors, to the agency that is related to each other within the given economic activity or geographical area and has an impact on the given community. The cornerstone of this approach is that the values, perspectives, perceptions, beliefs, and ideas of different actors fundamentally influence their own and others' economic activities. Instead of being passive sufferers of circumstances and environmental endowments, we see them as actors who actively shape their environment, activities, and opportunities, who receive constant impulses in a broader social context (DWIARTAMA - Rosin 2014). This perspective allows us to examine the differences between actors operating in nearly identical structures, the differences between more successful, more adaptable and less successful, more vulnerable firms, and their causes and motivations. From this point of view, we can also examine the production and sales strategies of farmers, their development, the learning and adaptation process that led to the current situation, and which may be important for the future. The role of networks also becomes important here, as in many cases different associations, collaborations and cooperatives offer opportunities not only to speed up learning processes, but also to overcome various threats and dangers (natural, economic, social) and to adapt to difficulties. This can be linked to the study of power inequalities and social justice, as the influence and advocacy capacity of different social and economic actors can be very different and variable (DARNHOFER et al. 2016). Resilience here is related to the first interpretation, as farming strategies are partly forced to adapt to different structures, however, they do not fully determine farmers 'decisions. Farming is not only an ecologically but also a socially defined process, it is the given medium, community or person who organizes its activities by different influences. Thus, resilience here is closely linked to farmers' learning skills and abilities, as well as their situational awareness and adaptability, and last but not least, their willingness to cooperate and their embeddedness in different, overlapping social networks (BEILIN et al. 2012). 
In the context of the sample areas, this appears as differences due to differences in the thinking of wine growers and wine producers, which determine the possibilities of the person, the farm. Various social norms that can be considered the legacy of the post-socialist past appear here, which are responsible, for example, for the degree of vertical and horizontal general trust, the willingness to cooperate and the use of past experience in the present (Szabó 2004). Phenomena related to peripheralization processes also appear, such as the backwardness resulting from the rural situation, the economic activities related to rurality, and the one-way dependence relations resulting from the sale of a low value-added product (NAGY - TIMÁR 2017). In addition, there is a degree of exclusion or stigma, which affects the quality of the wine region and the quality of the wines associated with the wine region. Also, the approach related to the peripheralization processes related to different communication discourses is explicitly connected to this, as on the one hand the image formed during political (local, regional, national, European) discourses, the image of the region itself, the farmers themselves and their responses they largely determine the vulnerability and potential resilience of farms (MEYER - MigGELBRINK 2013, LANG 2012). A concrete example is the large-scale independence aspirations of the winegrowers in both regions, which prevent the creation of a more efficient producer and / or sales cooperative with greater advocacy capacity. Also, in both regions is the presence of a dominant personality (or brand) who was among the firsts to recognize and successfully exploit the new opportunities and which in many cases serves as an example for later entrants. These leading actors are usually more deeply embedded in the wider social and economic networks, defining, and shaping the opinion, image and development directions of the region.

The resilience of a region, its community, its actors and their economic activities can be examined from a slightly different perspective, which does not focus specifically on entities (ecological and social), but on their constantly evolving relationships. In order to be clearly interpretable, we need to examine the medium in which farmers operate, without forgetting the peculiarity of the viewpoint that processes are imagined open-ended. Because everything is related to everything, it assumes constant change and opportunities that do not examine practices or relationships from the then and now perspective (DARNHOFER et al. 2016). Resilience is a trait that actors do not necessarily intentionally reproduce through their daily activities, which is thus embedded in the way people treat the material goods associated with their activities through different practices and in the symbolic meaning they associate with it (LENDVAY 2016).

In the sample areas, this perspective connects producers (winegrowers, winemakers) with the crop (grapes), products (wine, various other services), consumers, traders, different decision-makers and the natural environment in which they live and operate. In both sample areas, the separability arising from the quantitative and qualitative approaches can be observed, the producer group that produces large quantities of relatively low quality grapes and wine, as opposed to those who try to move more towards quality production and diversify their economic activities. This can be observed in the exchange of knowledge related to activities related to production (on-farm - grape varieties, cultivation methods, harvesting, etc.) and beyond (off-farm technology, wine varieties, packaging, sales, related services - eg. types of hospitality related to wine tourism, etc.), as well as in the joint or individual management of various social, economic and environmental changes. However, it is not necessarily possible to infer or directly state which of the strategies used by actors within a given community makes them more resilient, 
since, as one actor put it: "over time, it becomes clear how well a particular farmer is able to survive under given conditions". Yet, it is also necessary to see how these connections and their changes can flow smoothly and dynamically, as changes in their dynamics largely determine the possibilities of the connected actants.

\section{Conclusions}

Resilience thinking in multidisciplinary academic circles including geography has become exceptionally popular in western literature. While it has several coexisting, even conflicting meanings where resilience means an ability to change, and also an ability to remain in stable conditions, its meaning is determined by the disciplines, even its different approaches which altogether may obscure the concept. Resilience can be interpreted in many ways depending on who / what is placed in the study focus. Although there are many interpretations, with proper operationalization, although in many cases this is not the goal, some case studies may even allow comparative studies to be performed.

Based on the above, we can say that resilience is rooted in the structures of a system or a group, the elements of which determine how flexible it is. It can be resilient on the basis of the characteristics, properties and ideas of a group, the individuals that make it up, which, however, can make them both vulnerable and rigid if they are unable to adapt because of the structures they are embedded. The ANT enables the combined examination of structural and agency interpretation, which places the focus on the examination of the relations between the actors and their changes both in time and space. Based on these, it can be stated that basically the groups living in the post-socialist rural areas, which can be linked to various agricultural activities, are vulnerable, which, however, does not necessarily mean that they are not resilient in the neutral sense of the term, for it is precisely the structures that make them vulnerable, on the one hand that they insist to, and on the other hand, that they are involuntarily locked in. Through their activities, they become resilient in both positive and negative way, which they continually reproduce through their actions and relationships. Understanding these activities over time, i.e., rooted in their past, and in a broader geographical context, can predict the response to a potential negative event, i.e. the possible future path of the group, recognizing which we can take active action to prevent or prepare. However, this is not necessarily the task of the affected or examined groups, but also serves the interests of decision-makers, advocacy organizations and NGOs at different levels, which could provide an answer to the neoliberal critique of the concept.

\section{ACKNOWLEDGEMENTS}

This research was conducted as part of the doctoral study of the author and was partly supported by the NTP-NFTÖ-19-B Scholarship for Young Talents of the Nation of the Ministry of Human Capacities. 


\section{REFERENCES}

Adger, W. NeIL (2000): Social and Ecological Resilience: Are They Related? Progress in Human Geography vol. 24. no. 3. 347-364. https://doi.org/10.1191/030913200701540465

Antoce, A. OAna - Calugaru, A. Lidia (2017): Evolution of grapevine surfaces in Romania after accession to European Union - period 2007-2016. BIO Web Conf. vol. 9. no. 03018. https://doi.org/10.1051/bioconf/20170903018

Ashienazy, Amit - Tzruya, Chebach, C. - Knickel, Karlheinz - Sarah, Peter - Horowitz, BOAZ - OFFENBACH, RIVKA (2018): Operationalising resilience in farms and rural regions Findings from fourteen case studies. Journal of Rural Studies, vol. 59. 211-221. https://doi. org/10.1016/j.jrurstud.2017.07.008

Bajmócy Péter - Boros Lajos - Csatári Bálint - Dudás Renáta - Farkas Jenő Zsolt JuRAY TÜNDE - Kovács ZoltáN - NAGy GyUla - PÁl ViKTOR (2005): A globális klímaváltozás néhány társadalmi-gazdasági következménye. In RAKONCZAI JÁNOS - LADÁNYI ZsuZsANNA PÁL-MolnÁr Elemér (eds.): Sokarcú klímaváltozás. Szeged, GeoLitera, SZTE TTIK Földrajzi és Földtani Tanszékcsoport. 125-142.

Beilin, Ruth - Sysak, Tamara - Hill, Serenity (2012): Farmers and perverse outcomes: the quest for food and energy security, emissions reduction and climate adaptation. Global Environment Change vol. 22. no. 2. 463-471. https://doi.org/10.1016/j.gloenvcha.2011.12.003

BeKe Judit - Forgács ANNA - TARJÁN TAMÁs (2011): Európai Uniós országcsoportok mezőgazdasági teljesítményének összehasonlító vizsgálata. Gazdálkodás: Scientific Journal on Agricultural Economics vol. 55. no. 1. 1-13. https://doi.org/10.22004/ag.econ.119889

Berkes, Fikret - Folke, CARL (eds.) (1998): Linking social and ecological systems. Management practices and social mechanisms for building resilience. Cambridge, Cambridge University Press. 459.

Berkes, Fikret - Ross, Helen (2013): Community resilience: Toward an integrated approach. Society and Natural Resources vol. 26. no. 1. 5-20. https://doi.org/10.1080/08941920.2012.73 6605

Brown, D. DAVID - Kulig, C. Judith (1996): The concepts of resiliency: Theoretical lessons from community research. Health and Canadian Society vol. 4. no. 1. 29-52. https://opus.uleth. ca/handle/10133/1275

Brown, Katrina (2014): Global environmental change I: A social turn for resilience? Progress in Human Geography vol. 38. no. 1. 107-117. https://doi.org/10.1177/0309132513498837

CHIA, Robert (1999): A 'rhizomic' model of organizational change and transformation: perspective from a metaphysics of change. British Journal of Management vol. 10. no. 3. 209227. https://doi.org/10.1111/1467-8551.00128

Cretan, Remus - Guran, Liliana - Platon, Dan - Turnock, David (2005): Foreign Direct Investment and Social Risk in Romania: Progress in Less-Favoured Areas. In TURNOCK, DAVID (ed.) Foreign Direct Investment in Eastern Europe. London, Ashgate. 305-348. 
Cutter, Susan (2016): Resilience to What? Resilience for Whom? The Geographical Journal, vol. 182. no. 2. 110-113. https://doi.org/10.1111/geoj.12174

CSÁKi ,CSABA - JÁMBOR, ATTILA (2012): Az európai integráció hatása a középkelet-európai országok mezőgazdaságára. Közgazdasági Szemle vol. 59. 892-910. http://unipub.lib.unicorvinus.hu/888/1/Kszemle_CIKK_1328.pdf

Csávossy, György (2016): Erdély-Hegyalja, a borok hazája. Budapest, Kortárs Kiadó. 192.

Darnhofer, Ika - Lamine, Claire - Strauss, Agnes - Navarrete, Mireille (2016): The resilience of family farms: Towards a relational approach. Journal of Rural Studies vol. 44. 111-122. https://doi.org/10.1016/j.jrurstud.2016.01.013

Deleuze, Gilles - Parnet, Claire (1996): Dialogues. Paris, Flammarion. 157.

Dwiartama, AngGa - Rosin, Christopher (2014): Exploring agency beyond humans: the compatibility of Actor-Network Theory (ANT) and resilience thinking. Ecology and Society vol. 19. no. 3. no. 28. http://dx.doi.org/10.5751/ES-06805-190328

Foster, A. Kathryn (2006): A Case Study Approach to Understanding Regional Resilience. Texas, Institute of Urban and Regional Development. 45.

Garmezy, Norman (1973): Competence and adaptation in adult schizophrenic patients and children at risk. In Dean, R. Stanley (ed.) Schizophrenia: The first ten Dean Award lectures. New York, MSS Information. 163-204.

Herman, Agatha (2015): Enchanting resilience: relations of care and people-place connections in agriculture. Journal of Rural Studies vol. 42. 102-111. https://doi.org/10.1016/j. jrurstud.2015.10.003

Holling, C. S. (1973): Resilience and stability of ecological systems. Annual Review of Ecology and Systematics vol. 4. 1-23. https://doi.org/10.1146/annurev.es.04.110173.000245

Keck, Marcus - Sakdapolrak, Patrick (2013): What Is Social Resilience? Lessons Learned and Ways Forward. Erdkunde vol. 67. no. 1. 5-18. https://www.jstor.org/stable/23595352

LANG, Thilo (2012): Shrinkage, Metropolization and Peripheralization in East Germany. European Planning Studies vol. 20. no. 10. 1747-1754. https://doi.org/10.1080/09654313.20 12.713336

LÁszló, MÁRTON (2013): Kollektivizálás a Székelyföldön (1942-1962). Doktori disszertáció. Pázmány Péter Katolikus Egyetem.

Latour, Bruno (2005): Reassembling the Social: An Introduction to Actor-Network-Theory. Oxford, University Press. 301.

Lendvay, MÁrton (2016): Resilience in post-socialist context: The case of a watermelon producing community in Hungary. Hungarian Geographical Bulletin vol. 65. no. 3. 255-269. https://doi.org/10.15201/hungeobull.65.3.4

LIN, B. BRENDA (2011): Resilience in agriculture through crop diversification: adaptive management for environmental change. BioScience vol. 61. no. 3. 183-193. https://doi. org/10.1525/bio.2011.61.3.4 
Mălăescu, M. IoAna - Dobrei, Alina - Drăgunescu, Anca - Velicevici, Giancarla Nistor, EleONORA (2014): Studies concerning the development of viticulture on Arad, Timis and Caras-Severin areas. Journal of Horticulture, Forestry and Biotechnology vol. 18. no. 1. 96-103. https://www.journal-hfb.usab-tm.ro/romana/2014/Lista\%20lucrari\%20PDF/Vol\%20 18(1)\%20PDF/15Malaescu\%20Mihaela\%202\%20BUN.pdf

Martin, Ron - Sunley, Peter (2015): On the notion of regional economic resilience: conceptualization and explanation. Journal of Economic Geography vol. 15 no. 1. 1-42. https:// doi.org/10.1093/jeg/lbu015

Meyer, Frank - Miggelbrink, Judith (2013): The Subject and the Periphery: About Discourses, Loopings and Ascriptions. In Fischer-Tahir, Andrea - Naumann, Matthias (eds.): Peripheralization. Wiesbaden, Springer. 207-223.

MóD, LÁSZLÓ - SimON, ANDRÁs (2008): A Kárpát-medence borvidékei a dualizmus időszakában. Belvedere Meridionale vol. 20. no. 5-6. 34-61.

MolnáR, Zsolt (2003): A Kiskunság száraz homoki növényzete. Budapest, TermészetBÚVÁR Alapítvány. 160.

NAGY, ERIKA - TimáR, JUdit (2017): The (re-)production of peripherality in Central and Eastern Europe. European Spatial Research and Policy vol. 24. no. 2. 5-16. https://doi.org/10.1515/ esrp-2017-0006

Neugebauer, C. Silvia - Kovács, Zoltán (2015): Paths of Socio-Spatial Change in PostSocialist Cities - Insights from Five City-Regions in Central and Eastern Europe. In LANG, Thilo - Henn, Sebastian - Sgibnev, Wladimir - Ehrlich, Kornelia (eds.): Understanding Geographies of Polarization and Peripheralization. London, Palgrave Macmillan. 171-196.

SCHWARCZ, GyÖNGYI (2003): Mit ér a siker, ha soltvadkerti? Szociológiai Szemle no. 1. 118-136.

Scott, Mark (2013): Resilience: a Conceptual Lens for Rural Studies? Geography Compass vol. 7. no. 9. 597-610. https://doi.org/10.1111/gec3.12066

Sima, Michaela - Popovici, E. Ana - Bălteanu, Dan - Micu, Dana - Kucsicsa, Gheorge - Dragotă, Carmen - Grigorescu, Ines (2015): A farmer-based analysis of climate change adaptation options of agriculture in the Bărăgan Plain, Romania. Earth Perspectives vol. 2 no. 5. 1-21. https://doi.org/10.1186/s40322-015-0031-6

Szabó, KÁroly (2004): Az ezerarcú bizalom: a bizalom formáinak fejezetei. Szociológiai Szemle no. 3. 128-144.

SzÉKELY, Iván (2015): Reziliencia: a rendszerelmélettől a társadalomtudományokig. Replika vol. 94. no. 5. 7-23. http://www.replika.hu/system/files/archivum/94_01_szekely.pdf

TóтH, BALÁzs (2015): Regional economic resilience: concepts, empirics and critical review. Miscellanea Geographica - Regional Studies on Development vol. 19. no. 3. 70-75. https://doi. org/10.1515/mgrsd-2015-0017

TÖlgyesi, Csaba - TöröK, PÉter - HÁbenczyus, A. AnNA - BÁtori, Zoltán - VAlkó, Orsolya - DeÁK, Balázs - Tóthmerész, BÉla - Erdős, LÁszló - Kelemen, András (2020): Underground deserts below fertility islands? Woody species desiccate lower soil layers in sandy drylands. Ecography vol. 43. no 6. 848-859. https://doi.org/10.1111/ecog.04906 
Vannini, Phillip (2015): Non-Representational Methodologies. Re-Envisioning Research. New York, Routledge. 204.

WAlker, Brian - Holling, C. S. - CARPenter, R. Stephen - Kinzig, Ann (2004): Resilience, adaptability and transformability in social-ecological systems. Ecology and Society vol. 9 no. 2 no. 5. http://www.ecologyandsociety.org/vol9/iss2/art5/

Wilson, A. Geoff (2017): “Constructive tensions" in resilience research: Critical reflections from a human geography perspective. The Geographical Journal vol. 184 no. 1. 89-99. https:// doi.org/10.1111/geoj.12232

\section{OTHER SOURCES}

EUROPARL.EUROPA.EU (2020): Financing of the CAP. https://www.europarl.europa.eu/factsheets/ en/sheet/106/ financing-of-the-cap (2020.12.08.)

EC.EUROPA.EU (2020): Agriculture statistics - family farming in the EU. https://ec.europa.eu/ eurostat/statistics-explained/index.php/Agriculture_statistics___family_farming_in_the_ EU\#Structural_profile_of_farms_-_analysis_of_EU_Member_States (2020.12.08.)

EC.EUROPA.EU (2011): Archive:Urban-rural typology. https:/ec.europa.eu/eurostat/ statisticsexplained/index.php/ Archive:Urban-rural_typology (2020.12.08.)

EC.EUROPA.EU (2018): Territorial typologies manual - urban-rural typology. https://ec.europa. eu/eurostat/_statistics-explained/index.php/Territorial_typologies_manual_-_urban-rural_ typology\#Classes_for_the_typology_and_their_conditions (2020.12.08.)

INDEX (2019): Ha van a magyar okosságnak szívcsakrája, akkor az itt van. https://index.hu/ belfold/2019/11/ 11/az_aranyharomszog_ahol_mindig_van_valami_okossag (downloaded: 2020. 12. 08.).

CEICDATA (2020): Romania Foreign Direct Investment https://www.ceicdata.com/en/indicator/ romania/foreign-direct-investment (2020.12.08.)

ROMANIA-INSIDER (2017): 40\% of agricultural land in Romania belongs to foreign investors. https://www.romania-insider.com/agricultural-land-romania-foreign-investors (2020.12.08.) 